\title{
下部消化管手術における周術期抗菌薬投与期間の短縮化
}

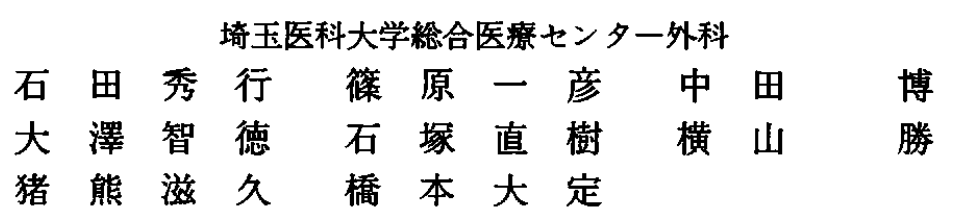

\section{A Brief Course of Perioperative Antimicrobial Prophylaxis for Colorectal Surgery}

\author{
Hideyuki ISHIDA, Kazuhiko SHINOHARA, Hiroshi NAKADA, \\ Tomonori OHSAWA, Naoki ISHIZUKA, Masaru YOKOYAMA, \\ Shigehisa INOKUMA and Daijo HASHIMOTO
}

Department of Surgery, Saitama Medical Center, Saitama Medical School

下部消化管手術における周術期抗菌莱投与の短縮化についてのprospective studyを行った。下部消化管待期手 術症例74例を对象に, 術前24時間以内にpolyethylene glycol 2Lでmechanical cleansingを行った後, kanamycin $1 \mathrm{~g}+$ erythromycin $0.8 \mathrm{~g}$ を 3 回経口投与した。加刀直前からcefotiamまたはcefmetazol $1 \mathrm{~g}$ を静注し， 3 時間を 超える手術では追加投与した。結腸手術では術当日ないし第 2 病日まで, 直腸手術では第 2 病日 (合計 $6 \mathrm{~g}$ )まで の投与に限定した。評価可能であった70例のsurgical site infectionはorgan/space infectionの 3 例（4\%）のみ で, incisional site infectionは 1 例も認めなかった。MRSA感染はorgan/space infection 2 例, remote infection 3 例の合計 5 例 $(7 \%)$ に認めたが, 重症例はなかった。以上の結果から, 下部消化管待期手術において, 術前 日から機械洗浄・化学洗净が開始される場合, 経静脈抗菌薬投与は第 2 病日までで十分であり, さらに短維化で きる余地があると考えられた。

乘引用䈃：下部消化管手術 (colorectal surgery), 周術期予防的抗菌薬投与 (perioperative antimicrobial prophylaxis), 術野感染 (surgical site infection), MRSA (Methicillin-resistant Staphylococcus aureus)

\section{はじめに}

わが国では従来，下部消化管手術における術野 感染阻止を目的に, 術前のmechanical cleansing に加え, 術前 $2 \sim 4$ 日程度の経口抗菌薬による chemical preparationが一般に行われていた ${ }^{12)}$ 。 ところが, 1980年代後半からの消化器外科手術後 のMRSA感染の頻発に对する反省から, 術前経口 抗菌薬の投与は控えられるようになり, 術後 3 〜 4 日間の経静脈的抗菌薬投与が推奨されてい

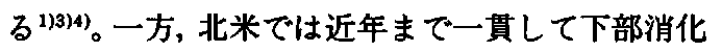

管手術前のごく短期間（多くは24時間以内）に経 口抗菌薬が投与され, 経静脈的抗菌薬の投与の追 加は術中ないし術後24時間以内に限られてい

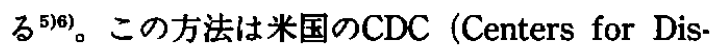

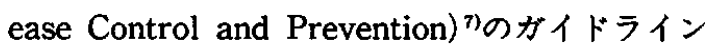
でも踏襲されているが，わが国では欧米とはリン パ節郭清や剥離範囲が異なること, 術後感染に対 する定義が異なることなどを理由に，CDCのガイ ドライン通りの周術期抗菌薬投与法を行うには慎 重を要するという見解が多い8)。近年わが国でも CDCのガイドラインに準じた方法について検討 
されつつあるが9, 実際の報告例はきわめて少な いのが現状である。今回, 下部消化管待期手術に おいて, 術前短期間のchemical preparationを行 い, 術中・術後の抗菌薬投与期間が, 従来わが国 で推奨されているより短期間で安全に行われうる かという点を明らかにすることを目的に，prospective studyを行ったので報告する。

\section{对象と方法}

\section{1. 対象}

2000 年 9 月から2001年 6 月までに当科下部消化 管チームが待期的に施行した下部消化管初回開腹 手術は87例あり，そのうちイレウスで腸管前処置 が不可能であった13例を除く74例を对象とした。 74例のうち, 術中の污染により抗菌薬を変更した 2 例, 術後投与期間が予定より長期間であった 1 例, 術前 2 週間以内にすでに抗菌薬の投与を受け ていた 1 例を除いた連続70例が評価可能症例であ った。70例の内訳（Table 1, 2) は，年龄： 14 91 (median, 64) 歳, 男女比：1.1で, 疾患は 大腸癌が57例と最も多く，ついで家族性大腸腺腫 症 4 例, 演疼性大腸炎 3 例などであった。術式で は結腸切除が29例と最も多く，ついで前方切除19 例, 八ルトマン手術 4 例, 結腸全摘 4 例, 大腸全 摘・回腸肛門 (管) 吻合 3 例, 腹会陰式直腸切断 術 3 例などであった。隣接あるいは転移䑏器の合

Table 1 Characteristics of patients

\begin{tabular}{cc} 
Male:Female & $37: 33$ \\
Age* & $64(14-91)$ \\
Diagnosis & \\
Colon cancer & 36 \\
Rectal cancer & 21 \\
Ulcerative colitis & 3 \\
Familial adenomatous polyposis & 4 \\
Others & 16 \\
Associated medical diseases & $16(23 \%)$ \\
Diabetes mellitus & 3 \\
Chronic renal failure & 3 \\
Liver cirrhosis & 3 \\
Ischemic heart disease & 1 \\
Brain infarction /Arthythmia & 3 \\
Steroid & 3 \\
Others & 3 \\
\hline
\end{tabular}

*: median (range)
併切除が6例（9\%）に行われた。その他に胆石 症を合併した 6 例に胆咅摘出術が，原発性アルド ステロン症を合併した 1 例に左副腎摘除が行われ た。手術時間は100 500 (median, 178.5) 分, 出 血量は10 2,000 (median, 132.5) gであった。併 存疾患としては糖尿病 3 例, 肝硬変 3 例, 慢性腎 不全 3 例，長期ステロイド投与が 3 例に認められ た。結腸痁26例のうち, 21例 (81\%), 直晹癌21例 のうち18例 (86\%) に 3 群リンパ節郭清が行われ た。術後重症合併症は 1 例も認められなかった。

\section{2. 方法}

Nichols ${ }^{5) 6)}$ の方法に準じて，術前24時間以内 にpolyethylene glycolによるmechanical cleansingを開始し，その 2 時間後より kanamycin(KM) $1 \mathrm{~g}$ およ゙゙erythromycin (EM) $0.8 \mathrm{~g}$ を 3 回経口投 与した。具体的には，手術開始が午前 $10 ： 00$ 頃の 予定の場合, 前日10：00からmechanical cleansingを開始し, KM+EMを13：00,14:00, $21 ： 00$ に服用した。加刀直前にcefotiam (CTM) $1 \mathrm{~g}$ ま たはcefmetazol(CMZ) $1 \mathrm{~g}$ を静腺投与し, 手術時 間が 3 時間を超える場合には， $1 \mathrm{~g}$ を追加投与し

Table 2 Characteristics of the procedures performed

\begin{tabular}{|c|c|}
\hline Surgical procedures performed & \\
\hline Standard colectomy & 29 \\
\hline Anterior resection & 19 \\
\hline $\begin{array}{l}\text { Abdomino-perineal } \\
\text { resection of rectum }\end{array}$ & 3 \\
\hline $\begin{array}{l}\text { Restorative proctocolectomy with } \\
\text { J-pouch reconstruction }\end{array}$ & 3 \\
\hline Total colectomy & 4 \\
\hline Hartmann's procedure & 4 \\
\hline Posterior pelvic exenteration & 1 \\
\hline Others & 7 \\
\hline $\begin{array}{c}\text { Synchronous resection of metastatic } \\
\text { or adjacent organs }\end{array}$ & $8(11 \%)$ \\
\hline Hepatectomy & 2 \\
\hline Hysterectomy +oophrectomy & 3 \\
\hline Others & 3 \\
\hline $\begin{array}{l}\text { Surgical procedures for concomitant } \\
\text { diseases }\end{array}$ & $7(10 \%)$ \\
\hline Cholecystectomy & 6 \\
\hline Adrenectomy & 1 \\
\hline Duration of surgery (min)* & $178.5(100-500)$ \\
\hline Blood loss $(g)^{*}$ & $132.5(10-2000)$ \\
\hline
\end{tabular}

*: median (range) 
た。結腸の定型手術の場合, 前処置も良好で, 術 中の污染も問題にならないと考えられた場合は術 当日のみの投与にととめたが, 前処置が不十分で あった狭寉のある症例や，糖尿病などの感染に対 するpoor risk症例に対しては，受け持ち医の判断 で第 2 病日 $(6 \mathrm{~g})$ までCTMまたはCMZを投与し た。直腸を切除する術式では第 2 病日まで一律に $6 \mathrm{~g}$ の $\mathrm{CM}$ またはCMZを投与した。 $\mathrm{CDC}^{7}$ 分類に 従ってsurgical site infection, remote infection の頻度・部位について検討した。また, surgical site infection, romote infectionを含めたMRSA

(Methicillin-resistant Staphylococcus aureus) 感染の頻度・部位についても検討した。

\section{成 績}

\section{1. 経静脈抗菌薬投与回数}

CTMが42例 (61\%)，CMZが28例（39\%）に使 用された。直腸切除を含む術式の場合, 全例に予 定通り $6 \mathrm{~g}$ (6 回)の投与が行われていた。結腸手 術では43例中 31 例 $(72 \%)$ に術当日に限り，1 $\mathrm{g}$ $\sim 3 \mathrm{~g}$ ( $1 \sim 3$ 回) の投与が行われ, その他の 12 例 (28\%) には $6 \mathrm{~g}$ （6 回）の投与が行かれていた (Fig. 1)。

\section{Surgical site infection}

Surgical site infectionのうち, incisional site infectionは 1 例もなく, organ/space infectionが 3 例（4％) に認められた（Table 3 )。3例の内 訳であるが, 1 例は60歳, 男性で, 下部直腸癌に 対L, 腹会陰式直腸切断術 (中枢側 $\mathrm{D}_{3}$, 側方 $\mathrm{D}_{3}$ ) 施行後, 骨盤底の感染が生じ, MRSAが分離され た。また横行結腸癌・膵浸潤に対し, 横行結腸切 除・脾体尾部・脾合併切除 $\left(\mathrm{D}_{3}\right)$ 老行った75歳, 女性では, 術後膵液のminor leakから感染を併発 L, Staphylococcus epidermidisが分離された。ま た, 慢性腎不全で透析中の55歳, 男性のS 状結腸癌 に対し, S状結腸切除 $\left(\mathrm{D}_{2}\right)$ を施行後, ドレーンの 感染が第 6 病日から認められ, MRSAが分離され た。第12病日に吻合部のminor leakが確認された が, 保存的に軽快・治癒した。

\section{MRSA感染}

上記に提示したorgan/space infectionの 2 例 (Case 1, 2) 以外に, 3 例のremote infection

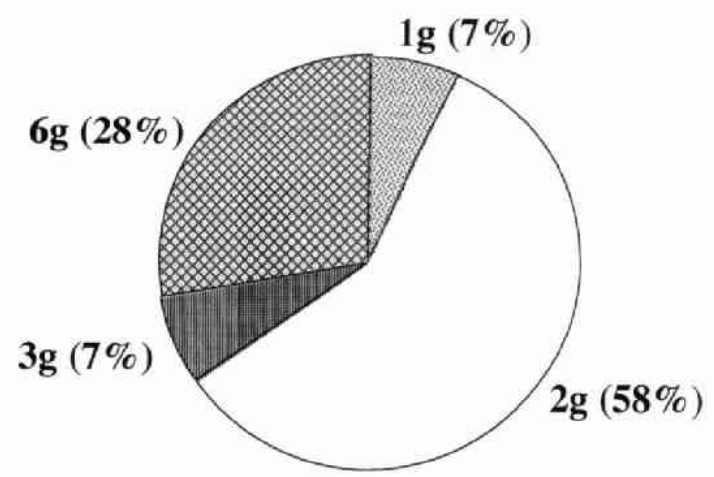

Fig. 1 Doses of cefotiam or cefmetazol administered in 43 patients undergoing colon surgery.

Table 3 Surgical site infections

\begin{tabular}{ll}
\hline Overall surgical site infection & $3(4 \%)$ \\
Incisional site infection & $0(0 \%)$ \\
Organ/space infection & $3(4 \%)$ \\
anastomotic leak & $1(1 \%)$ \\
without anastomotic leak & $2(3 \%)$ \\
\hline
\end{tabular}

を加えた合計 5 例のMRSA感染が認められた (Table 4)。Case 3 は原発性アルドステロン症を 合併した75歳, 女性で, S状結腸癌に対し, ハルト マン手術 $\left(\mathrm{D}_{2}\right)$ と左副腎摘除を施行した。脳梗塞 後で術後も十分な経口攝取ができず，中心静脈栄 盖を続けていたところ，MRSAによる中心静脈力 テーテル感染から, 細菌性心内膜炎を併発したが, バンコマイシンの経静脈投与で軽快した。Case 4 とCase 5 は術後 $3 \sim 4$ 日に $38^{\circ} \mathrm{C}$ 台の発熱と下痢 で発症したMRSA腸炎であったが，バンコマイシ ンの経口投与で軽快した。

\section{考察}

今回の結果からみる限り, 術前短期間の経口抗 菌薬によるchemical preparationが行われる場 合, 周術期の経静脈的抗菌薬投与期間は結腸手術 でおおむね術当日のみ，直腸手術でも術当日を含 めて 3 日間で十分であることが明らかになった。 今回の検討を始める前に, 結腸手術の一部とすべ ての直腸手術でも術当日の投与のみに限定するこ とも考慮したが，現在のかが国のガイドライン で術後 $3 \sim 4$ 日間が推奨されている限り, 縫合不 
Table 4 Patients with MRSA infection

\begin{tabular}{|c|c|c|c|c|c|c|c|}
\hline$C_{n e v}$ & Abe & $\operatorname{sex}$ & Divenese & Operation performed & Associnted disenese & $\begin{array}{l}\text { Pereatural } \\
\text { antibjotics }\end{array}$ & Site of MRSA infection \\
\hline 1. & 60 & Male & Reotel cancer & $\begin{array}{l}\text { Abdomino-perineal } \\
\text { resection (D3) }\end{array}$ & $(-)$ & CMZ, 6 & $\begin{array}{l}\text { Organdepuce } \\
\text { (Petvic space) }\end{array}$ \\
\hline 2. & 35 & Malo & Colon cenneer & Sigmoidectomy $\left(\mathrm{D}_{2}\right)$ & Chronic reanal failure & CTM, 28 & 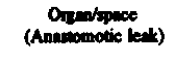 \\
\hline 3. & 75 & Fensile & Colon cancer & $\begin{array}{l}\text { Hertmenn's procedture } \\
\left(D_{2}\right) \text { theft atrenectomy }\end{array}$ & $\begin{array}{l}\text { Brin infarction, } \\
\text { primary } \\
\text { aldoweronista }\end{array}$ & CTM, 6g & $\begin{array}{c}\text { Remole sile } \\
\text { (Cubeter infoction) }\end{array}$ \\
\hline 4. & 67 & Male & Colow cencer & $\begin{array}{l}\text { Right hemicolectony } \\
\left(D_{y}\right)\end{array}$ & $(-)$ & CTM, 28 & $\begin{array}{l}\text { Renote site } \\
\text { (Enteritis) }\end{array}$ \\
\hline 5. & 85 & Mne & Colon cencer & $\begin{array}{l}\text { Right hemicolectomy } \\
\text { (D3) }\end{array}$ & $\begin{array}{l}\text { Pulmonary } \\
\text { emphyseces }\end{array}$ & CTM, 2\& & $\begin{array}{l}\text { Remowe site } \\
\text { (Enteritis) }\end{array}$ \\
\hline
\end{tabular}

MRSA: Methicillib-resistont Staphylococous abrews

全や骨盤膡瘍のriskが高い直腸手術では術中を含 めて 3 日間，結腸手術でも症例によっては 3 日間 の投与を許容範囲としたことはやむを得なかった。 今回の検討には，前処置が不十分になりがちな 狭窄を有する症例や, poor risk症例も含まれてい ることを考えれば，その成績は満足すべきと考え られる。特にsurgical site infection全体が $4 \%$ と 低率で, しかもincisional site infectionが 1 例も みられなかったことは注目に值すると考えされ る。最近の報告によれば, 下部消化管術後のsurgical site infectionの頻度は2.9 21.4\% ${ }^{23) 9) \sim 11) て ゙ ~}$ あるが, 施設間でかなり差があることが指摘され ている。今回の検討を始める直前の当科でのran-

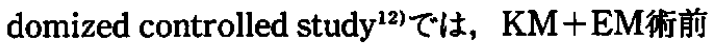
2 日間投与群と非投与群(两群ともCTMを術中か ら 3 日間投与) の腹壁創感染の頻度はそれぞれ 5 \%, 16\%であり，今回の結果の方がいずれの群よ クもすぐれていると考えられる。

MRSAに对する对策が十分に行われるように なった今日でも, 消化器外科術後に分離される細 菌の中ではMRSAが最も多い10)。龟岡ら ${ }^{13)}$ は，下 部消化管手術後のMRSAの検出率が $11.3 \%$, 腸炎 発生が $4.5 \%$ と報告している。しかしながら，この 点についての詳細な報告例はきわめて少なく, 実 態は不明である。今回の検討ではMRSA感染が 7 \%にみられた。当科で以前行った randomized controlled study ${ }^{12)} て ゙ は ， \mathrm{KM}+\mathrm{EM}$ 術前 2 日間投 与群, 非投与群のMRSA感染頻度はそれぞれ12 \%，5\%であった。今回の結果はそれらの中間に
位置するものであるが，重症化した症例はないこ とと， 5 例中 3 例はpoor risk症例であったことを 考えると，その発症頖度についてはやむを得ない と考えられる。下部消化管術後のMRSA感染の原 因として第 1 に，術前経口抗菌萝と術中・術後の 経静脈的抗菌莱の投与の双方が菌交代現象や耐性 菌の選択に影響を与えたためと考えられる。しか しながら，今回の方法のように術前24時間以内の chemichal preparationのみではそのような有害 現象を起こしにくいと考えられており ${ }^{14)}$, 術中·術 後経静脈的抗菌薬の投与期間のさらなる短縮化に よって，MRSA感染率を低下させられるか否か が、今後の検討課題であると思われる。

医療费削減の面から考之れば，術前短期間の経 口抗菌薬の投与と術当日のみの経静脈的抗菌薬投 与の方が, 術後 3〜 4 日間の経静脈的抗菌薬投与 より推奨されるべきであることは明らかである。 今回の検討から，少なくとも䊅腸手術の場合，お おむね前者の方法がわが国の手術方法にも適応し うることを確認することができた。今後，直腸手 術でも術中・術後の経静脈的抗菌莱投与期間を術 当日ないし術翌日程度までに短縮できるかといっ た点について,検討する必要があると考えられる。

\section{結䃌}

下部消化管待期手術において, 術前短期間 (24 時間以内) のchemical preparationが行われる場 合，結腸手術ではおおむね術当日，直腸手術でも 術当日を含めて 3 日間の経静脈抗菌薬投与で十分 
下部消化管手術における周術期抗菌薬投与期間の短縮化

な術野感染阻止効果が得られることが確認され た。直腸手術における術後抗菌薬投与期間のさら なる短縮化が今後の課題である。

本稿の要旨は第26回日本外科系連合学会学術集会 （2001年 6 月，東京，要望演題：感染・炎症）で発表 した。

\section{类考文献}

1）炭山嘉伸，横山 隆：消化器外科における抗生剂 の使用法をめぐって．日消外会誌 $27 ： 2358-2367$, 1994

2）古川清菁，恩田昌彦，鈴木英之他：大腸手術にお ける予防的抗菌莱投与法. 外科 $63 ： 153-156,2001$

3）谷村 弘, 由良二郎, 松田静治他：術後感染発症 阻止薬の臨床評価に関するガイドライン (1997年 度版)。旦化療会誌 $45 ： 553-641,1997$

4）品川長夫, 真下啓二, 岩井重富他：術後感染予防 についてのアンケート報告. 日消外会誌 $33 ： 1559$ $-1563,2000$

5) Nichols RL, Condon RE, Gorbach SL, et al: Efficacy of preoperative antimicrobial preparation of the bowel. Ann Surg $176: 227-232,1972$

6) Nichols RL, Smith JW, Garcia RY, et al: Current practices of preoperative bowel preparation among North American colorectal surgeons. Clinical Infectious Disease 24 : 609-619,
1997

7) Mangram AJ, Horan TC, Pearson ML, et al : Guideline for prevention of surgical site infection. Infect Control Hosp Epidemiol 20 : 247280,1999

8）炭山嘉伸，有馬陽一：術後の抗菌薬予防投与はど こまで減量可能か。外科 $63 ： 138-142,2001$

9) Takasue Y, Yokoyama T, Akagi S, et al:A brief course of colon preparation with oral antibiotics. Surg Today $30: 112-116,2000$

10）小山 勇：消化器外科手術における予防的抗菌 薬短期間投与の効果. 外科 $63: 133-137,2001$

11）橋爪 正, 梅原 実, 板橋幸弘他：大腸癌待機手 術における予防的抗菌薬の至適投与法。外科 63 ： $157-162,2001$

12）石田秀行, 横山 勝, 橋本大定他：下部消化管手 術後の術野感染・MRSA感染と術前抗菌薬投与. 外科 $63: 163-166,2001$

13）亀岡信吾, 板橋道明，桐田孝史他：下部消化管術 後MRSA検出例および腸炎発症例の検討. 日本大 晹肛門病会誌 $47 ： 100-105,1994$

14) Nichols RL, Broid P, Condon RE, et al : Effect of preoperative neomycin-erythromycin intestinal preparation on the incidence of infectious complication following colon surgery. Ann Surg 178 : 453-462, 1973 